\title{
Situating South Africa's Past, Present and Future
}

\author{
John W. Forje \\ Department of Political Science \\ University of Yaoundé 11-Soa \\ Post Box 13429 Yaoundé Cameroon \\ E-mail:jowifor@yahoo.fr
}

Shakela Bukingu, John Daniel, Roger Southall and Jessica Lutchman \{eds.\} [2007]. State of the Nation - South Africa. Publishers - Human Science Research Council \{HSRC\} Press, ISBN 978-0706921888. Price R200.00, Paperback. 586 pages.

Adrian Hadland, Eric Louw, Simphire Sesanti and Herman Waiserman [2008] Power, Politics and Identity in Southern African Media. Human Science Research Council \{HSRC\}.ISBN 978-0-7969-2202-1. Price R180.00. Paperback. 403 pages,

Haroon Bhorat \& Ravi Karibup \{eds.\} [2006]. Poverty and Policy in Post Apartheid South Africa. Publishers - Human Science Research Council \{HSRC\} Press ISBN. 0-7969-2122-9. Price R285.00. Paperback 471 pages

Vishnu Papayachee \{ed.\} [2006]. The Development Decade - Economic and Social Change in South Africa, 1994-2004. Publishers - Human Science Research Council \{HSRC\} Press ISBN. 0-7969-2123-7 Price

Nombonniso Gasa \{ed.\} [2007] Women in South African History. Publishers Human science Research Council \{HSRC\} Press. ISBN 978-0-7969-2179-1 Price R210.00 paperback 458 pages

Richard Calland \& Paul Graham \{ed.\} [2005]. Democracy in the Time of Mbeki. Publishers - Institute for Democracy in South Africa \{IDASA\}, Cape Town. ISBN 1-919 798-88-9: 13-978-1-919798-88-2. Price. Not given Paperback. 252 pages

Mcebisi Ndletyana \{ed.\} [2008] African Intellectuals in the $19^{\text {th }}$ and Early $20^{t h}$ 
Century South Africa. Publishers: Human science Research Council \{HSRC\} Press. ISBN 978-0-7969-2207-6 Price R100.00, Paperback 76pages

Andre Kraak \& Karen Press [2008] Human Resources Development Review 2008: Education, Employment and Skills in South Africa. Publishers Human Science Research Council \{HSRC\} Press ISBN 978-07969-2203-8. Price R380.00 Paperback 640pages

Since the collapse of apartheid in 1994, South Africa has made tremendous progress in the process of constructing a capable developmental state to ensure sustainable development for the common good of its people. Both the mass media and knowledge production units (universities and research centres) have been active in the process. The books under review here document and comment on such effort. These books are in fact indicative of the state of intellectual maturity and discourse in the country; the determination to develop and properly utilise human capital resources, the state of freedom and quality of publishing which few African countries can march. The analyses and interpretations as offered by the various scholars depart from different analytical theoretical framework. Some of the interpretations are critical of government policies and state institutions but have the goals of aiding government to be transparent and correcting certain wrongs in society.

The State of Nation Report [2007]. This compact book comprising 22 chapters, surveys the political, economic, social, security and environmental health of the country. Grouped under four main themes, Politics, Economy, Society, Foreign Affairs, the book penetrates the annals of an emerging society, depicting the strength, weakness, opportunities and threats faced by the continent's most prosperous state.

In the introductory chapter Roger Southall argues that 'state capacity' is a critical aspect of South Africa becoming a developmental state. State capacity is characterised within the realm of four dimensions: ideational, political, implementational and technical. How has South Africa been able to meet the formidable challenges that fall under these headings? Of course, opinions vary, even though it is probably true to state that there is a growing consensus around implementation and technical dimensions than around ideational and political capacities. The presidency of Mbeki comes under sharp focus. Southall goes further to contrast the regime of Mandela and that of Mbeki by stating that Mandela's presidency was characterised by the drive for national unity and racial reconciliation; while that of Mbeki sought to give substance to the ANC's perception of its historical role to structure a modern democracy out of the legacy of apartheid. [See Daniel et al. 2005]. 
Following the 1996 Constitution of South Africa which effectively went operational on $4^{\text {th }}$ February 1997, the objectives of local government were established under three domain; \{i\}democratic and accountable government; \{ii\}the provision of services to communities in a sustainable manner; and\{iii\} facilitating the involvement of communities and associated organisations in local governance; activities which enhance the era of participatory developmental local government and thereby deepening democracy in the country [Reddy et al 2005]. The process continued even after the rift within the ANC and Mbeki's forced resignation in 2008 and as the country faced the 2009 elections.

The State of the Nation Report gives the reader a picture of the changing political dynamics in South Africa. It remains an interesting annual publication depicting unfolding socio-political and cultural evolutions in the rainbow nation. It remains an important reference book which raises and answers important questions on the socio-economic, environmental and cultural setting of South Africa. The treatment of the various subjects is nuanced and the writing is simple, accessible, packed with useful statistical data and information for further exploitation by scholars. The contributors have done a marvelous job in piecing together systematically issues confronting South Africa.

Power, Politics and Identity in Southern African Media [2008] is a collection of essays presented at an international conference in Stellenbosch, South Africa, in July 2006 as part of a project to excavate the space between media and identity. The media, of course, have many forms, just as identity has many variations. The media do generate, corroborate and accelerate identity formation, just as they diminish, overshadow and negate it. The variety of essays included in this volume reflects the various forms this process took during the first decade of democracy in South Africa.

The contributors concentrate on the 'double moment' of change and continuity paying attention to racism and identity. The book is organised into three sections. The first section focuses on "Identity in Theory" and has five contributions beginning with "Media, Youth and Violence in South Africa" by Abebe Zegeye who sees identity as 'people's source of meaning and experience' \{Castells 1999:6-7\}. In the discussion of essentialism, Kees van der Waal emphasises the challenges to studies of identity, culture and language. He points out that all forms of essentialism need to be questioned and seen as political attempts to frame constructions in a specific way, based on a set of interest and relationships. He goes on to address Neo-Afrikaner nationalism, as an ethnicisation process and a tool of the transfer of power by Afrikaans-speaking whites to a mainly African elite that prioritises the use of English to access the world of work and knowledge. He points out the importance of the political economy of language: "in order to get rid of the myth of purity and essentialism that are crippling 
successful dialogue, it is necessary to embrace variety and process in their place."

The paper by Ruth Teer-Tomaselli looks at the relationship between the public broadcaster, the public, the nation and the state and problematises the way that the concept 'has been applied to media with an almost canonical reverence'. She goes to streamline the fact that the confluence of South Africa's democratising process and accelerated globalisation places the South African public broadcaster in a precarious position. Section two "Media Restructuring and Identity Formation After Apartheid" has five contributions and explores in a more detailed way, South Africa's media which have undergone massive changes in the wake of the country's political transformation from apartheid to democratic rule.

A significant trend in the post-1994 print media is the arrival of tabloid newspapers. In 1994, the biggest selling daily newspaper with an average of 191322 copies per day was The Star of Johannesburg. By 2006, the Daily Sun was selling over 450000 copies daily with a daily readership of 3.44 million. The authors note the arrival of the tabloids, and the controversy among media analysts. First, commentators bemoaned the apparent poor journalism of the tabloids which they considered was construed within dodgy ethics and pandering to the lowest common denominator. Nicolas Jones et al. present critical thoughts in their analysis noting that "while tabloid journalism may have many faults, it can also be seen as alternative arena for public discourse."

Tanja Bosch in "Online Coloured Identities" examines how the meaning of 'coloured' is explored on the Internet. She states that "coloured identity is linked more to global notions of blackness than to a South African black identity: coloured identity is still more than a dated apartheid label: it has been invented and reinvented". Anthea Garman's analysis of Antije Krog's "Country of My Skull" uses the experience of reporting on the Truth and Reconciliation Commission $\{\mathrm{TRC}\}$ to illustrate this notion and contemplates its implications for identity formation. Apparently, the TRC has become South Africa's export commodity in reconciliation, peace-building, post-conflict resolution and reconstruction in enhancing the democratisation process across the world. South Africa was deformed and destroyed by apartheid, and Garman's paper is a contribution to understanding the political and developmental context and role of the media in identity formation after apartheid.

The last section focuses on different identity formations. The paper by Simphiwe Sesanti "The Media and Zuma/Zulu Culture: An Afrocentric and Contemporary South African Media "adopts a form of perennialism to understand identity. By and large this section offers a series of case studies depicting the tensions and struggles associated with the birth of a new and mutation of old identities in contemporary South Africa. Wiida Fourie's paper "Afrikaner Identity in PostApartheid South Africa: The Self in terms of the Other" reveals how Afrikaners 
are adjusting to the post-apartheids environment. He draws out core features of Afrikaner identity which remain resistant to change.

Anita Howarth's paper on identity is different from other contributions insofar as it focuses on government's attempts to manufacture a state identity. The author argues that South Africa's collective identity constructed and popularised since 1994 is now under threat due to struggles over how South Africa should respond to the Zimbabwe crisis; a crisis which is undermining some elements of the 'self-vision' South Africans have constructed of themselves. If Howarth is correct, South Africans may end up reconceptualising their collective vision, which would reconstruct key elements of their collective identity.

Democracy in the Time of Mbeki edited by Calland and Graham [2005] presents Thabo Mbeki as the pre-eminent political figure in the consolidation of democracy in South Africa. Nelson Mandela is the hero and global icon securing and giving international prominence to the struggle for, an ultimate acquisition of, democratic majority rule. Section 1 - "Index: Scoring South Africa's Democracy" scores the country on issues as 'participation and democracy' [11 questions with a score 6.2]; 'elections and democracy' [33 questions with a score of 7.2]; 'accountability and democracy' [20 questions with a score 5.7]; 'political freedom and democracy' [18 questions with a score of 6.9]; and 'human dignity and democracy' [18 questions with a score of 4.7]. There is a total of 100 questions with a total score of 6.3 . The index assesses the state of democracy and the extent to which all are contributing to the general well-being of society or eroding it. The democracy index is by the Institute for Democracy in South Africa (Idasa).

Section 2 "Context: Contemporary thoughts on Democracy" provides some conceptual context, with a series of contemporary thoughts about democracy - 'A Symbiotic Relationship - Business And Democracy'; 'Black Economic Empowerment - Capital and Democracy'; 'The Politics of Centralisation Citizens and Democracy'; 'Mixed Signals - Women and Democracy'; 'South Africa in the World - Foreign Policy and Democracy'; 'Social activism Globalisation and Democracy'. Section 3 - Analysis: Applying Idasa's Index'. Here the index is applied by five scholars for their critical analysis. The section begins with 'Real Citizenship - Participation and Democracy'; 'An Active Electorate - Elections and Democracy'; 'Servants of the People - Accountability and Democracy'; 'Political Freedom - Equality and Democracy'; 'Inequality lives on - Human Dignity and Democracy'.

The study is an attempt to measure South Africa's progress in achieving and maintaining stability and order, change and promote the wellbeing of the least advantaged, within a rights-based constitutional. The book tries to take the pulse of South Africa's transition to democratic governance and its consolidation. Apparently, there is no short cut to democratisation. Nevertheless, the country 
has made significant strides towards the establishment and consolidation of democracy. Since the collapse of the apartheid governance system the political landscape has changed for the better. The creation of new institutions to promote and protect democracy gives the country an edge over other African nations which the various authors attempt to address from their different disciplines. It is an interesting publication depicting the reality that the new South African democracy is alive and kicking.

African Intellectuals in the $19^{\text {th }}$ and Early $20^{\text {th }}$ Century edited by Mcebisi Ndletyana [2008] is an introduction to the lives and works of five exceptional Africa intellectuals based in the former Cape Colony in the nineteenth and early twentieth centuries. This unique study recounts and preserves a part of African intellectual heritage which is not widely known. In reviewing this book, one draws inspiration from the 1998 Nobel Prize Laureate for Economics, Amartya Sen's [2005] publication. The slim volume of 76 pages does not do justice to African Intellectuals'. Nonetheless, the book establishes the premises of understanding literary traditions, culture and religions within the African context. By and large, the book creates the anvil to understand and distinguish the role an individual plays in the transformation of a society. Thus the publication is 'timely and its value is timeless' and gives a voice to Africans in a manner that makes us 'understand how they interpreted and reacted to colonial conquest and the missionary proselytizing project'[pxi].

The book profiles the lives and works of five individuals: Ntsikana, Tiyo Soga, John Tengo Jabavu, Mpilo Walter Benson Rubusana and Samuel Edward Krume Mqhayi. These early intellectuals, based in the Cape, owed their rise to the cumulative impact of missionary activities, as well as to British colonialism. The Missionaries first arrived among Xhosas in September 1799.

Ntsikana conceptualised and constructed his religious belief in a pattern that attracted and accommodated the various cultural dimensions of his people. Because of this fusion, Ntsikana could advance Christian beliefs within the African community. Tiyo Soga was the first internationally educated South Africa and priest, a pioneer of African literature, and a seminal intellectual. Tiyo Soga embodied the paradox of the civilising mission, personified the modernising influence of the missionary enterprise, but was also an indictment of the supposed moral virtue of the colonial establishment. He had a brief but illustrious life span of only 42 years, but turned his educational training towards awakening the very same national pride and consciousness that his missionary teachers had denounced.

Soga's ideas were the precursor of nationalist thought, and sowed the seeds of black consciousness and black theology in South Africa. Black consciousness was to given a new kiss of life by Steve Biko in the 1970s leading to a new break path 
for the demise of the apartheid governance system which finally came in 1994 . John Tengo Jabavu was a pioneer of African journalism and champion of higher education for Africans and a controversial figure who woefully depended on white-liberal agency. Ultimately, he was a very conflicting figure. Tengo excelled at an early age in literature and mathematics and repeatedly won many academic competitions.

Mpilo Walter Benson Rubusana, educationist, journalist and politician who started his early childhood herding livestock, and went to school at the age of 16. He was part of a team that established more than 10 schools in and around East London; helped in providing and expanding formal education to Xhosa children. Rubusana advocated for compulsory education and went further than others in advocating mother-tongue education. His contribution to literature and history earned him an Honorary PhD from the McKinley Memorial University in Louisville, Kentucky in the United States, in 1906. His great works in the country were destroyed by the apartheid regime - the schools and churches were demolished during the apartheid programme of forced removal in the 1960s and 1970s when thousands of African inhabitants of East London were uprooted to Mdantsane, a township in the Ciskei homeland 30 miles away. He passed away on 19 April 1936.

A renowned poet and author, Samuel Edward Krune Mqhayi embodied the transition of African narratives from the oral tradition to the written word. He fused his natural talent for oratory and story-telling with his literary training to produce the first ever literary collection by an imbongi - a poet and keeper of history. Mqhayi did not advocate that blacks put political and economic power towards the destruction of a white presence among them. Rather, he pleaded for racial cooperation, counseling that whites could become agents for good. He used poetry and the biblical analogy of a spear that, even though it is a lethal weapon can also be turned into a life-sustaining plough. His many texts reveal an intense interest in a variety of social issues.

This is a book of inspiration that should appeal strongly to the youths and for the senior citizens to dig deep into the libraries and rediscover the continent's lost intellectuals.

Poverty and Policy in Post Apartheid South Africa edited by Bhorat and Kanbue [2006] is a massive publication, 471 pages with 11 papers. The political freedom ushered after 1994 was seen as the basis for redressing long standing economic deprivations suffered by the majority of the population. The reduction of poverty in all its facets was high on the political agenda. This volume attempts an evaluation of this goal. Generally, the papers, individually and collectively, present an overview of the changing dynamics of the political, economic and social landscape of the new South Africa, drawing implications for policy articulation 
in the second decade of the country's post-apartheid governance system. 'How well has South Africa done?' still remains a subject of debate. No doubt there has been progress in the economy, the critical issues remain poverty and inequality has been fought.

The various essays reflect this point. The conclusion of the authors is that: (a) there is an increase in both absolute and relative income poverty; (b) there has been an increase in income inequality, which is notably being catalysed by a rise in the share of within-group inequality; (c) despite some employment growth, the rapid expansion of the labour force has resulted in increased unemployment rates irrespective of the definitions used; (d) a large and swift fiscal resource shift has engendered widened access to assets and basic services for poor households; and (e) these changes in poverty and well-being in the post-1994 period have occurred within, and have influenced and been influenced by, an environment of tepid economic growth rates.

This is a publication of immense value to researchers, government ministries, policy-makers, international agencies, non-governmental organisations and students at all levels.

Women in South African History [edited by Nomboniso Gasa 2007] is a rich collection of texts and narratives, by 15 authors revisiting the task of writing South Africa's history from an overtly feminist perspective, giving readers an opportunity to understand and reflect on debates about women's power and location in new and fresh ways. The 458 page book takes readers on a long journey through the major themes of the country's history - colonial period through the struggle of the apartheid era to the present 'rainbow nation' making genuine efforts to consolidate its independence. The problems are not solved and remain challenging.

The introduction, "New Freedoms and New Challenges, a Continuing Dialogue" by Nomboniso Gasa, sets the premise of the book which examines the texture, confluences, narratives and nuances that are so powerful a part of the history of South Africa. The central thread running through the different phases of South Africa's history is the quest for emancipation. The desire for crossing rivers and moving boulders constitutes the constant struggles and movements of women; movements that at times were seen as unimportant and not warranting official documentation.

Admittedly, gender, feminism, womanism and African feminism all constitute a complex discourse with variant positions taken by the pros and cons of the subject. While not penetrating much into the debate, it can be pointed out that there are many academics, activists, politicians and policy-makers who associate feminism with Euro-American, Anglo-Saxon and Occidental traditions. There are of course those who argue that the very concept of feminism is out of place in 
the African context. Yet the underlying reality is that women of African descent have been looking at ways in which their cultural and historical realities can be taken as point of departure in feminist scholarship and world view. Many writers have sought to address this vital topic [Oyewumi 1997; Walker 1983; Amaidume 1997; Hooks 1981] have made invaluable contributions in taking some of these issues forward and highlighting the limitations of the mainstream Euro-American feminist discourse.

This book is a significant contribution not only to South African historiography and feminist literature but of an invaluable input to the enter struggle for gender equality and recognition of the role and contributions by women in the nation struggle.

The Development Decade? Economic and Social Change in South Africa, 1994-2004 with Vishnu Padayachee as editor covers an impressive breadth of issues. The 471 page publication has as contributors scholars like Dani Nabudere; Jonathan Michie Adam Habib, Rashad Cassim, Eleanor Preston-Whyte, Kuben Naidoo, Dale McKinley, Julian May, Haroon Bhorate to name but a few.

Locating the South African challenges within the broader international perspective, the issues covered include all the major development challenges confronting South Africa - employment, HIV/AIDS and health policy, industrial policy, urban governance, poverty, inequality, the informal economy, social challenges, ethnic divide, and human resources development. The key development debates of the post-apartheid period are outlined and the success or failures of the past decades of reform, reconstruction and experimentation is considered from holistic and scientific perspectives.

Development Decade is a publication in 8 sections with 23 well-researched papers. The paper by Vishnu Padayachee, "Development Discourses in PostApartheid South Africa" notes that "the period in post-apartheid South Africa reminds one of what Philippe Hugon, writing about Francophone thinking in development economics, calls the "period of modernisation.” South Africa's development discourse is preoccupied with issues such as: the level and rate of unemployment, whether poverty and inequality are getting worse, how big is the informal economy? What is the HIV/AIDS status of the country? Looking at contemporary debates in a global context, Section 1 is examines African and South African development discourse within the context of a critique of the major theories of development that have emerged in the past 50 or more years, depicting the rise, fall and resurrection of 'development theory' in the post-war period, as well as the continuities and discontinuities in the way these theories have impacted on countries Africa. The contributors to this section include Gillian Hart and Dani Wadada Nabudere.

Section 2 "Macroeconomic Balance and Microeconomic Reform" examines 
the initial wave of economic reforms in the country after the transition in 1994 and provides a rich account of the country's economic reform process. It looks at the employment effects of macroeconomic reforms in terms of both the performance and the possible options for the future. Distributive issues in post-apartheid South Africa constitute the topic discussed in Section 3 with contributions by Julian May and Francie Lund. The focus is on how the new government addressed the legacies of the racially determined poverty and inequality issues. What has government performance been in the past decade? What policies and programmes have made a difference? Section 4 focuses on global competitiveness, industrial upgrading and innovation with papers by Jo Lorentzen, Mike Morris, Glen Robbins and Justin Barnes. The papers look at South Africa's industry rapidly shifted from an import-substituting industrialization growth path towards one of engaging with the competitiveness demands of the global economy. This required a new industrial policy environment and new government support measures were necessary to assist manufacturing enterprises in meeting these challenges. The authors equally grapple with the question of how demand for knowledge especially by firms incorporated and articulated within discrete national and regional contexts. Equally, the authors examine the role of government in facilitating cluster development with a focus on the auto sector in developing countries.

Section 5 discusses issues concerning municipal governance and development with contributions from Christian Rogerson, Benoit Lootvoet and Bill Freund. Basically, the 1996 Constitution fundamentally changed local government into an independent sphere of government, seen as the "hands and feet" of reconstruction and development in South Africa. Using this as the premise of departure, it is pointed out that within Africa, the greatest progress in decentralisation is recorded in post-apartheid South Africa [Ndegwa 2002; Nel \& Rogerson 2005] and, significantly, the country is now emerging as a pioneer in terms of local economic development (LED) on the African continent.

Section 6 deals with labour, work and the informal economy with contributions from Haroon Bhorat, Richard Devey, Caroline Skinner and Imraan Valodia. The paper by Haroon Bhorat looks at labour supply and demand constraints on job creation, noting that there has been a significant reconceptualisation of the notion 'informal economy'. First the post-apartheid labour market has experienced 'jobless growth' and the economy in the aggregate, has been creating jobs rather than shedding them. Second, in terms of both labour supply and labour demand, there exist significant microeconomic constraints, operating at the level of the household and firm, which remain a constraint on employment creation. Third, the role of information and knowledge networks was severely undermined for the 70 percent of the unemployed, as the employed and union 
members were predominantly located in the middle-to-upper end of the expenditure distribution. And lastly, the 'pro-poor' orientation of the social grants has a labour market variant.

The issue of population, health and development is taken up in Section 7 with four papers concentrating on how to incorporate health practices and health technology into everyday life of all segments of society. Health remains an important catalyst between population and sustainable development. A healthy society is a productive and progressive society. Issues such as coping with illnesses and deaths in post-apartheid South Africa, condoms in marital and cohabiting partnerships and development issues around HIV/AIDS are discussed.

The topic of Section 8 is on social movements. Two poles of opinion are identified with regard to civil society. The one view is that civil society should be a unified volunteer sector that aims to assist the democratic state to implement its agenda; the other that civil society should constitute itself as a set of countervailing forces that can and should challenge state and corporate power. The papers by Habib, Imraan Valodia and Richard Ballard review these new social movements and assess their significance for the consolidation of South African democracy. Other sections look at why the new social movements are likely to remain outside of the mainstream of the country's institutional politics and why the poor may no longer view active participation within our 'representative democracy' as being in their interests.

The Development Decade depicts progress made by post-apartheid South Africa, looks at prevailing challenges as well as maps out strategies that can move and consolidate South Africa's developmental process. It remains a well researched and documented book which readers interested in the theories of development and the practical realities of transformation will find very useful.

Human Resources Development - Education, Employment and Skills in South Africa 2008 edited by Andree Kraak \& Karen Press with 25 chapters, provides an extensive overview of the contextual factors driving human resources development in South Africa. The contributors point to the multi-faceted skills development strategy operating at three levels; (i) high skills policies aimed at expanding export-oriented manufacturing production and services provision particularly in new globally competitive 'niche' areas; (ii) the economy's ongoing need for intermediate skills, evident in the shortage of skilled artisans and technologists; and (iii) the provision of basic, entry-level skill for large scale job creation schemes, triggered by public sector initiatives, to ameliorate high levels of unemployment and despondency, especially amongst the youth and women.

The book points out certain flaws in human resources development noting that even though structural changes have occurred in South Africa since the collapse of apartheid towards greater capital and skills-intensity, these changes 
have not dramatically reduced the demand for sufficient numbers of technically competent operatives, artisans and technicians in the manufacturing sectors of the economy. Secondly, the economy is characterised by greater poverty, unemployment and low levels of labour absorption. The expansion of entry-level jobs in labour-absorbing sectors is of crucial importance to South Africa's future prosperity. The book takes up issues covered in the 2003 volume with many updated sections. Most importantly, the various chapters in the HRD Review 2008 are strongly influenced by the three-level conception of skills development in the 2003 edition. The book is well illustrated with tables, diagrams and other useful statistical materials. It remains an essential user friendly resource for policy makers, managers, researchers and educators at all levels.

\section{Conclusion: Where Do We Go From Here?}

The strength and weakness of South Africa as a nation state can be seen through these books. The progress made so far are encouraging pointing towards better days ahead. But hard work, commitments and responsibility by all as well as shared prosperity are required in constructing a capable developmental state. Though South Africa is on the right track, much more is required to give this rainbow nation a kiss of life. Largely united, but tragically still deeply unequal, plagued by poverty, unemployment and still struggling to entrench the basic tenets of democracy, South Africa enters its second decade of democratic governance, strong and confident, and with resolve to do better as it approaches its third decade of independence.

As Calland and Graham [2005] note; "this is no time for complacency; having laid such a foundation, it must be used as a springboard for the full emancipation of South Africans." These publications show the necessity of building the critical mass for development. The books are well researched and written in readable language and appeal to a wide cross-section of the reading public, students, policy-makers, government officials, academics, international organisations, nongovernmental organisations. South Africa is reconstructing its past in order to build a sustainable future. This requires all hands on deck. 


\section{References}

Amaidume Ifi [1997] Re-inventing Africa: Matriarchy, Religion and Culture. Zed books. London

Amaidume Ifi [1987] Male Daughters, Female Husbands: Gender and Sex in an African Society. Zed Books. London

Bronwyn Harris [www.csvr.org.za/papers/paphar1.htm]

Bond Patrick [2004]"From Racial to Class Apartheid: A Critical Appraisal of South Africa's Transition", Paper presented to the AIDC's 10 years of Democracy, Cape Ton 27 November 2004

Castells M. [1999]. The Information Age: Economy, Society and Culture. Vol.2.

The Power of Identity. Blackwell Publishers, Oxford

Chumbow Beban Sammy [2005] "The Language question and National

Development in Africa"; in Thandika Mkandawire (ed.) 2005 African

Intellectuals, CODESRIA Book Series, Dakar - Senegal, pp165-192

Coleman, P.T. [2000] "Intractable Conflicts." In The Handbook of Conflict Resolution: Theory and Practice (eds.) m. Deutsch \& P.T. Coleman [2000] Jossey-Bass Publishers, San Francisco, CA

Cowen , Michael \& L. Laakso [2002] "Election and Election Studies in Africa," in M. Cowen and L. Laakso \{eds. 2002 Multi-party Elections in Africa. James Currey, Oxford

Daniel J, Southall R. \& Lutchman L. [2005] "Introduction: President Mbeki's Second Term: Opening the Golden Door", in Daniel et al \{eds.\} State of The Nation 2004-2005. Cape Town HSRC Press

Hooks Bell [1981] Ain't I a Woman: Black Woman and Feminism. South End Press, Boston.

Hooks Bell [1989] Talking Back: Thinking Feminist, Thinking Black. South End Press, Boston

Hugon P. [1991] "The Three Periods of Francophone Thinking in Development Economics", European Journal of Development Research 3. December Lugalambi, G.W, [2001] "the Role of Mass Communications in Preventing Conflict." In E. Sidiropoulos \{ed.\} A Continent Apart: Kosovo, Africa and Humanitarian Intervention, The South African Institute of International Affairs, Johannesburg, South Africa, pp89-102

Mamdani,M. [1995] And Fire Does Not Always Beget Ash: Critical Reflections on the NRM. Monitor Publications, Kampala

Masuku, S. [2003] "For Better and for Worse: South African Crime Trends in 2002", in South Africa Crime quarterly No.3 March 2003, Institute for Security Studies, Pretoria, South Africa, p.3

McLuhan Marshall [1964] Understanding Media: The Extensions of Man. MIT 


\section{Press, Cambridge, USA}

Molefe, P. [2003] News Coverage in Africa. Presentation at Highway Africa.

Rhodes University. South

Moran, A. [1998] Copycat TV: Globalisation, Program Formats and Cultural Identity. University of Luton Press, Luton, UK

Mulvey, L. [2003] "Visual Pleasure and Narrative Cinema" in Jermyn D. and Brooker W. [2003] The Audience studies Reader. Routledge, London Ndegwa S. [2002] Decentralisation in Africa: A Stocktaking Survey. African Working Paper Series No.40, Washington, DC: World Bank

Nel E. \& Rogerson C. \{eds.\} [2005] Local Economic Development in the Developing World: The Experience of Southern Africa. Transaction Press. London

Nnoli, O. [1998] "Ethnic Conflicts in Africa: A Comparative analysis." In Ethnic Conflicts in Africa. Edited by O. Nnoli, CODESRIA Book Series, Dakar - Senegal, pp1-25

Oyewumi Ayoronke [1997] The Invention of Women: Making an African sense of Western gender discourses. University of Minnesota Press, Minneapolis, USA

Reddy P.S, Naidoo P \&Pillay P [2005] Local Democracy and Developmental Local Government in South Africa Beyond the First Decade: Quo vadis? $35(2): 40-52$

Sen. Amartya [2005] The argumentative Indian: Writings on Indian Culture, History and Identity

Stephens, M. [1997] A History of the News. Harcout Brace \& Company, Orlando, Florida

South African Democracy Education Trust $\{$ SADET $\}$ [2004] The Road to

Democracy in South Africa, Vol.1 \{1980-1970\}. Zebra Press. Cape Town

Southall Roger [2006] "Introduction: Can South Africa be a Developmental State"? In S. Buhlungu et al. \{eds.\} State of the Nation: South Africa 2005-2006. Cape Town, HSRC Press

Sunday Vision [2003] Gae, Abby Have Sex on Live TV June 29, 2003, The Vision Printing \& Publishing Co. Kampala, p1.

Tandon, Y. [2000] "Root Causes of Peacelessness and Approaches to Peace in Africa.” Peace \& Change 25:166-187

Tettey J. Wisdom [2001] "The Media and Democratisation in Africa: Contributions, Constraints and Concern of the Private Press", Media Culture \& Society, Vol. 23 No.1 [3-31].

The Daily Telegraph [2001] "Yes, These Shows are Exploitative, Says Mr. Big Brother:July19,2001pp1.http://www.telegraph.co.uk/news/2001/07/19. 
Accessed on August 25, 2003

The United Nations Development Programme \{UNDP\} 2003. Human Development Index 2003 Country Report, Uganda. New York, NY: UNDP

Walker Alice [1983] In Search of our Mother's Gardens. Harcourt. San Diego 